\title{
Sikap Bahasa Masyarakat Dusun Mangento Desa Pattontongan terhadap Penggunaan Bahasa Indonesia
}

\author{
Kasmawati, Fitrawahyudi, Desy Sulung Saputri \\ Pendidikan Bahasa dan Indonesia, FKIP, Universitas Muslim Maros \\ kasma89@umma.ac.id, Fitrawahyudi@Umma.ac.id, desysulung82@gmail.com
}

\begin{abstract}
Abstrak
Penelitian ini bertujuan untuk mendeskripsikan sikap bahasa masyarakat Dusun Mangento Desa Pattontongan terhadap penggunaan bahasa Indonesia. Permasalahan yang diteliti adalah bagaimana sikap bahasa masyarakat Dusun Mangento Desa Pattontongan terhadap penggunaan bahasa Indonesia. Subjek penelitian ini adalah masyarakat Dusun Mangento. Penelitian ini menggunakan metode penelitian gabungan (mixed methods) antara metode penelitian kualitatif dan kuantitatif. Tekhnik pengumpulan data yang digunakan adalah observasi, angket dan wawancara. Sampel dalam penelitian ini diambil 21\% dari jumlah keseluruhan masyarakat Dusun Mangento Desa Pattontongan yang berjumlah 885 orang sehingga didapatkan hasil sebanyak 40 responden dijadikan sebagai sampel. Penelitian ini menggunakan teori ciri-ciri sikap bahasa yang dikemukakan oleh Garvin dan Mathiot, yaitu (1) kesetiaan bahasa, keinginan seseorang atau masyarakat dalam mendukung bahasa, untuk memelihara dan mempertahankan bahasa, bahkan kalau perlu mencegahnya dari pengaruh bahasa lain; (2) kebanggaan bahasa yaitu keyakinan terhadap bahasa yang tertanam pada diri seseorang untuk menjadikan bahasa tersebut sebagai identitas diri; (3) Kesadaran akan norma bahasa, suatu posisi/keadaan seseorang untuk patuh terhadap suatu aturan. Berdasarkan persentase angket sebesar 8,5\% sangat setuju dan $34,5 \%$ setuju, jawaban ragu-ragu diperoleh sebesar $18 \%$, tidak setuju sebesar $38 \%$ dan sangat tidak setuju sejumlah $1 \%$ serta hasil pengamatan dan wawancara yang dilakukan penulis menunjukkan bahwa sikap bahasa masyarakat Dusun Mangento Desa Pattontongan terhadap penggunaan bahasa Indonesia adalah negatif.
\end{abstract}

Kata Kunci: Sikap, sikap bahasa, bahasa Indonesia

\section{Pendahuluan}

Sikap bahasa tidak bisa lepas dari sosiolinguistik. Sikap bahasa masyarakat Indonesia tidaklah sama, diantara mereka ada yang bersikap positif dan ada juga bersikap negatif. Kenyataan tersebut dapat dilihat bahwa seseorang yang menggunakan suatu bahasa sangat mempengaruhi bahasa yang digunakannya dalam kehidupannya sehari-hari. Di Dusun Mangento, Desa Pattontongan, kecamatan Mandai, kabupaten Maros, bahasa Indonesia jarang sekali digunakan dalam berkomunikasi dan berinteraksi antar sesama, di desa ini bahasa Indonesia tidak berkembang dengan baik. Masyarakat di desa ini lebih sering menggunakan bahasa daerah, dibanding dengan menggunakan bahasa Indonesia yang merupakan bahasa Nasional. Berdasarkan hasil wawancara dengan responden yang tinggal di daerah tersebut, yang diwawancarai pada hari minggu tanggal 15 Desember 2019, pukul 14.30 waktu Indonesia tengah.

Garvin dan Mathiot (dalam Chaer dan Agustina, 2014:152) mengemukakan tiga ciri sikap bahasa yaitu: 1) kesetiaan bahasa (language loyalty) yang mendorong masyarakat suatu bahasa mempertahankan bahasanya, dan apabila perlu mencegah adanya pengaruh bahasa lain; 2) kebanggaan bahasa (language pride) yang mendorong orang mengembangkan bahasanya dan menggunakannya sebagai lambang identitas dan kesatuan masyarakat; dan 3) kesadaran adanya norma bahasa (awareness of the norm) yang mendorong orang menggunakan bahasanya dengan cermat dan santun, dan 
merupakan faktor yang sangat besar pengaruhnya terhadap perbuatan yaitu kegiatan menggunakan bahasa (language use) ketiga ciri yang dikemukakan Garvin dan Mathiot di atas merupakan ciri-ciri sikap positif terhadap bahasa. Sebaliknya, kurang menyukai, kurang peduli, dan tidak bangga terhadap bahasa daerah atau bahasa Indonesia menunjukkan sikap negatif. Berkenaan dengan sikap bahasa negatif terhadap bahasa Indonesia, Sikap negatif bahasa akan menyebabkan orang acuh tak acuh terhadap pembinaan dan pelestarian bahasa. Mereka menjadi tidak bangga lagi memakai bahasa sendiri sebagai penanda jati diri bahkan mereka merasa malu memakai bahasa itu.

Itulah alasan mengapa penulis ingin melakukan penelitian mengenai sikap bahasa dengan judul, "Sikap bahasa masyarakat Dusun Mangento Desa Pattontongan terhadap penggunaan bahasa Indonesia". Tujuan dari penelitian ini adalah untuk mengetahui bagaimana sikap bahasa masyarakat Dusun Mangento Desa Pattontongan terhadap penggunaan bahasa Indonesia

\section{Metode}

Penelitian ini dilakukan pada bulan Mei sampai Juli Tahun 2020. Penelitian dilakukan di wilayah kabupaten Maros, Provinsi Sulawesi Selatan, tepatnya di kecamatan Mandai, Desa Pattontongan, Dusun Mangento. Penelitian ini dikaji melalui dua pendekatan penelitian, yaitu pendekatan kualitatif dan kuantitatif. Mixed method menghasilkan fakta yang lebih komprehensif dalam meneliti masalah penelitian, karena peneliti memiliki kebebasan untuk menggunakan semua alat pengumpul data sesuai dengan jenis data yang dibutuhkan. Metode ini dipilih karena cocok dengan karakteristik masalah penelitian, yakni sikap bahasa masyarakat Desa Pattontongan Dusun Mangento terhadap penggunaan bahasa Indonesia, yang berlangsung secara alamiah.

Jumlah sampel yang ditentukan pada penelitian ini yaitu sebanyak $21 \%$ dari jumlah populasi sebanyak 885 orang sehingga sebanyak 40 responden dijadikan sampel. Dalam metode ini penelitian menggunakan Sampling Insidental yaitu tekhnik menentukan sampel berdasarkan kebetulan dan siapa saja yang secara kebetulan bertemu dengan peneliti dapat digunakan sebagai sampel, bila dipandang cocok sebagai sumber data.

Adapun teknik pengumpulan data dalam penelitian ini adalah observasi, angket, dan wawancara. Metode observasi digunakan untuk mengamati masyarakat berinteraksi dan berkomunikasi dengan cara merekam video kegiatan masyarakat. Metode angket digunakan untuk menjaring data dari responden terkait dengan sikap bahasa masyarakat dusun Mangento terhadap penggunaan bahasa Indonesia. Metode wawancara digunakan untuk mendukung hasil jawaban dari kuesioner yang disebar agar memperoleh data atau jawaban dari responden dan sesuai dengan data yang diharapkan peneliti.

\section{Hasil Penelitian}

Berdasarkan penelitian yang dilakukan, dapat diperoleh data keseluruhan hasil angket/kuesioner yang disebar mengenai sikap bahasa terhadap penggunaan bahasa Indonesia yaitu sebagai berikut

Sikap bahasa masyarakat Dusun Mangento terhadap penggunaan bahasa Indonesia dapat dibagi dalam ciri-ciri sikap bahasa menurut Garvin dan Mathiot yaitu kesetiaan bahasa, kebanggaan bahasa, dan kesadaran norma bahasa. Dari keseluruhan pernyataan angket mengenai sikap bahasa yang berkaitan dengan kesetiaan bahasa, 
kebanggan bahasa, dan kesadaran norma bahasa, terdapat data keseluruhan dari alternatif jawaban angket yaitu, sangat setuju sebanyak 34 responden, setuju 138 responden, jawaban ragu-ragu sebanyak 72 responden, kemudian tidak setuju sebanyak 152 responden dan sangat tidak setuju sebanyak 4 responden.

\section{Pembahasan}

Sikap bahasa masyarakat Dusun Mangento terhadap penggunaan bahasa Indonesia terdapat 10 daftar pernyataan yang disajikan pada angket. Hasil pertanyaan wawancara berpedoman dari jawaban angket yang dipilih oleh responden. Kemudian hasil wawancara dan pengamatan yang diteliti oleh penulis.

a) Kesetiaan Bahasa

Kesetiaan bahasa adalah seseorang yang mempunyai keinginan atau masyarakat dalam mendukung bahasa, mempertahankan bahasa, bahkan jika perlu mencegahnya dari pengaruh bahasa lain.

\section{Pernyataan 1}

Saya selalu menggunakan bahasa Indonesia dalam komunikasi sehari-hari Tabel 1

\begin{tabular}{lcc}
\hline Alternatif Jawaban & Frekuensi & Persentase \\
\hline Sangat Setuju & 3 & 7,5 \\
Setuju & 10 & 25 \\
Ragu-ragu & 12 & 30 \\
Tidak Setuju & 15 & 37,5 \\
Sangat Tidak Setuju & - & - \\
\hline \multicolumn{1}{c}{ Jumlah } & 40 & $100 \%$ \\
\hline
\end{tabular}

Dari 40 responden, sebanyak 13 responden dengan rincian 3 memilih jawaban sangat setuju dan 10 memilih jawaban setuju. Responden memilih sangat setuju pada pernyataan selalu menggunakan bahasa Indonesia dalam komunikasi sehari-hari karena bahasa Indonesia adalah bahasa yang digunakan responden sehari-hari. Sedangkan yang memilih setuju, mereka mengaku terbiasa menggunakan bahasa Indonesia sehari- hari dan merasa lebih nyaman ketika menggunakan bahasa Indonesia sehari hari dalam berkomunikasi. Selanjutnya 12 responden yang memilih jawaban alternatif ragu-ragu. Menurut pengamatan penulis, dan hasil wawancara, responden menggunakan bahasa Indonesia dalam komunikasi sehari-hari, tergantung situasi yang mereka hadapi. Jika lawan tuturnya menggunakan bahasa daerah, mereka juga akan membalas berkomunikasi dengan menggunakan bahasa daerah. Dan ketika lawan tuturnya menggunakan bahasa Indonesia mereka juga akan menggunakan bahasa Indonesia. Menurut hasil wawancara pada responden nomor 14 mengaku menggunakan bahasa Indonesia jika berkomunikasi dengan anak-anaknya yang masih duduk di bangku sekolah. Responden mengaku sejak dini mengajarkan anaknya menggunakan bahasa Indonesia agar tidak terbiasa menggunakan bahasa daerah ketika berada dilingkungan sekolah. Selanjutnya 15 responden mengaku tidak setuju. Ketika diwawancarai mereka mengaku tidak menggunakan bahasa Indonesia dalam komunikasi sehari-hari karena keseharian responden sudah terbiasa menggunakan bahasa daerah dalam berkomunikasi. 


\section{Pernyataan 2}

Saya Menyukai Bahasa Indonesia

Tabel 2

\begin{tabular}{lcc}
\hline \multicolumn{1}{c}{ Alternatif Jawaban } & Frekuensi & Persentase \\
\hline Sangat Setuju & 13 & 32,5 \\
Setuju & 26 & 65 \\
Ragu-ragu & 1 & 2,5 \\
Tidak Setuju & - & - \\
Sangat Tidak Setuju & - & - \\
\hline \multicolumn{1}{c}{ Jumlah } & 40 & $100 \%$ \\
\hline
\end{tabular}

Pada pernyataan responden menyukai bahasa Indonesia, hampir keseluruhan memenuhi indikator sikap bahasa berkaitan dengan kesetiaan bahasa. diperoleh 39 responden dengan rincian 13 memilih alternatif jawaban sangat setuju dan 26 memilih jawaban setuju. Responden sangat setuju dan setuju menyukai bahasa Indonesia mengaku, karena bahasa Indonesia adalah bahasa sehari-hari yang digunakan dalam berkomunikasi dan berinteraksi. Sebagian mengaku karena responden adalah warga negara Indonesia. Namuun ketika berinteraksi dan berkomunikasi sebagian masyarakat cenderung menggunakan bahasa daerah. Menurut pengamatan penulis sebagian responden hanya sekedar mengaku menyukai bahasa Indonesia tetapi dalam tindakan ketika berinteraksi dan berkomunikasi mereka menggunakan bahasa daerah. Mereka mengaku lebih mudah menggunakan bahasa daerah dari pada bahasa Indonesia. Kemudian 1 responden mengaku ragu-ragu menyukai bahasa Indonesia, karena responden mengakui bahwa ia tidak tahu menggunakan bahasa Indonesia. Responden mengaku menyukai bahasa Indonesia tetapi tidak biasa menggunakan bahasa Indonesia. Kesehariannya hanya menggunakan bahasa daerah. Kemudian sebanyak 40 responden tidak ditemukan memilih jawaban tidak setuju dan sangat tidak setuju pada pernyataan angket kedua.

\section{Pernyataan 3}

Saya lebih senang menggunakan bahasa Indonesia dari pada bahasa daerah ketika berbicara kepada orang yang lebih tua dari saya

Tabel 3

\begin{tabular}{lcc}
\hline Alternatif Jawaban & Frekuensi & Persentase \\
\hline Sangat Setuju & 1 & 2,5 \\
Setuju & 11 & 27,5 \\
Ragu-ragu & 9 & 22,5 \\
Tidak Setuju & 19 & 47,5 \\
Sangat Tidak Setuju & - & - \\
\hline \multicolumn{1}{c}{ Jumlah } & 40 & $100 \%$ \\
\hline
\end{tabular}

Sebanyak 12 responden dengan rincian 1 responden mengaku sangat setuju dan 11 responden memilih alternatif jawaban setuju, mereka mengaku sudah terbiasa menggunakan bahasa Indonesia ketika berbicara kepada orang yang lebih tua dari responden. Selanjutya 9 responden mengaku ragu-ragu pada pernyataan ketujuh yang berkaitan dengan kesetiaan bahasa. Dari hasil wawancara responden yang memilih alternatif jawaban ragu-ragu, mereka hanya menggunakan bahasa Indonesia kepada orang yang lebih tua, apabila orang yang lebih tua menggunakan bahasa Indonesia kepada responden. Jika orang yang lebih tua menggunakan bahasa daerah kepada responden, responden juga akan menggunakan bahasa daerah. Jadi responden yang 
memilih jawaban ragu-ragu beralasan menggunakan bahasa Indonesia terhadap orang yang lebih tua hanya tergantung situasi yang mereka hadapi. Namun orang tua di dusun Mangento cenderung berinteraksi dan berkomunikasi dengan menggunakan bahasa daerah. Adapun yang menjawab tidak setuju sebanyak 19 responden. Mereka mengaku terbiasa menggunakan bahasa daerah dilingkungan tempat tinggalnya. Orang tua cenderung terbiasa menggunakan bahasa daerah. Bahasa daerah lebih santai dan lebih nyaman digunakan dari pada bahasa Indonesia. Bahasa Indonesia hanya digunakan jika Mereka berada pada situasi yang cenderung seseorang menggunakan bahasa Indonesia.

Kesimpulan yang didapat dari ciri kesetiaan sikap bahasa adalah negatif. Dari pernyataan angket 1, 2, dan 3 yang disebar masyarakat dusun Mangento lebih banyak yang menggunakan bahasa daerah dalam komunikasi sehari-hari. Masyarakat hanya sekedar menyukai bahasa Indonesia tetapi dalam tindakan mereka berinteraksi dan berkomunikasi menggunakan bahasa daerah. mereka lebih senang menggunakan bahasa daerah ketika berkomunikasi kepada orang yang lebih tua dari responden. Bahasa Indonesia hanya digunakan jika lawan tutur menggunakan bahasa Indonesia.

b) Kebanggan bahasa

Responden yang bangga terhadap bahasa Indonesia akan lebih sering dan cenderung menggunakan bahasa Indonesia. bahasa Indonesia dijadikan sebagai identitas diri.

\section{Pernyataan 4}

Saya bangga terhadap bahasa Indonesia

Tabel 4

\begin{tabular}{lcc}
\hline Alternatif Jawaban & Frekuensi & Persentase \\
\hline Sangat Setuju & 7 & 17,5 \\
Setuju & 22 & 55 \\
Ragu-ragu & 8 & 20 \\
Tidak Setuju & 3 & 7,5 \\
Sangat Tidak Setuju & - & - \\
\hline \multicolumn{1}{c}{ Jumlah } & 40 & $100 \%$ \\
\hline
\end{tabular}

Dari 40 responden, 7 responden memilih sangat setuju dan 22 responden setuju pada pernyataan bangga menggunakan bahasa Indonesia. Responden yang memilih sangat setuju karena bahasa Indonesia adalah bahasa persatuan bangsa Indonesia. responden yang menjawab sangat setuju mengaku karena dengan bahasa Indonesia responden dapat berinteraksi dengan orang luar yang menggunakan bahasa Indonesia. selanjutnya terdapat 8 responden memilih alternatif jawaban ragu-ragu. Responden mengaku bangga terhadap bahasa Indonesia dan bahasa daerah karena responden orang Indonesia dan dari suku makassar. Sebanyak 3 responden tidak setuju pada pernyataan saya bangga terhadap bahasa Indonesia. menurut pengakuan responden no urut 10 mengaku tidak bangga terhadap bahasa Indonesia karena responden tidak tahu menggunakan bahasa Indonesia. sebanyak 40 responden tidak ditemukan alternatif jawaban sangat tidak setuju. 


\section{Pernyataan 5}

Saya lebih bangga ketika menggunakan bahasa Indonesia dari pada bahasa daerah Tabel 5

\begin{tabular}{lcc}
\hline Alternatif Jawaban & Frekuensi & Persentase \\
\hline Sangat Setuju & 3 & 7,5 \\
Setuju & 12 & 30 \\
Ragu-ragu & 13 & 32,5 \\
Tidak Setuju & 12 & 30 \\
Sangat Tidak Setuju & - & - \\
\hline \multicolumn{1}{c}{ Jumlah } & 40 & $100 \%$ \\
\hline
\end{tabular}

Pada pernyataan angket saya lebih bangga ketika menggunakan bahasa Indonesia dari pada bahasa daerah, juga terlihat negatif dari hasil wawancara yang dilakukan. 3 responden sangat setuju, dan 12 responden setuju. Responden yang memenuhi indikator sikap bahasa berkaitan dengan kebanggaan bahasa, mengaku sangat setuju karena responden terbiasa menggunakan bahasa Indonesia dan bahasa Indonesia lebih mudah digunakan dari pada bahasa daerah. responden yang memilih alternatif jawaban setuju mengaku karena bahasa Indonesia adalah bahasa yang digunakan responden untuk berkomunikasi dalam keseharian. Selanjutnya 13 responden menjawab raguragu. Responden mengaku bahwa mereka bangga terhadap kedua bahasa, yaitu bahasa Indonesia dan bahasa Makassar. Mereka menggunakan bahasa tergantung situasi yang mereka hadapi. jika situasi yang mereka hadapi banyak yang menggunakan bahasa Indonesia, responden akan bangga menggunakan bahasa Indonesia. jika situasi yang mereka hadapi dominan menggunakan bahasa daerah responden juga akan bangga menggunakan bahasa daerah. Namun masyarakat di Dusun Mangento cenderung menggunakan bahasa daerah. Artinya masyarakat di dusun Mangento lebih cenderung bangga terhadap penggunaan bahasa daerah. Kemudian 12 responden memilih alternatif jawaban tidak setuju. Responden yang diwawancarai mengaku bahasa daerah juga penting digunakan untuk berkomunikasi dengan orang-orang yang menggunakan bahasa daerah.

\section{Pernyataan 6}

Saya mengakui bahwa bahasa Indonesia

lebih menarik dari pada bahasa daerah

Tabel 6

\begin{tabular}{lcc}
\hline \multicolumn{1}{c}{ Alternatif Jawaban } & Frekuensi & Persentase \\
\hline Sangat Setuju & - & - \\
Setuju & 17 & 42,5 \\
Ragu-ragu & 8 & 20 \\
Tidak Setuju & 15 & 37,5 \\
Sangat Tidak Setuju & - & - \\
\hline \multicolumn{1}{c}{ Jumlah } & 40 & $100 \%$ \\
\hline
\end{tabular}

Kebanggaan bahasa Indonesia juga dapat dilihat ketika responden mengakui bahwa bahasa Indonesia lebih menarik dari pada bahasa daerah. Dari angket yang disebar dan hasil wawancara yang dilakukan kepada respoden, tidak ada responden memilih jawaban sangat setuju. Terdapat 17 responden setuju. Responden mengaku bahwa bahasa Indonesia sudah terbiasa digunakan, dan lebih mudah diucapkan dari pada bahasa daerah. Kebanyakan yang mengaku setuju pada pernyataan mengakui 
bahwa bahasa Indonesia lebih menarik dari pada bahasa daerah adalah usia 11 tahun sampai 38 tahun. Selanjutnya sebanyak 8 responden memilih jawaban alternatif raguragu. Bahasa Indonesia dan bahasa daerah dianggap sama-sama menarik. Tergantung dari lawan tutur menggunakan bahasa apa kepada responden. ketika orang yang diajak berbicara maupun berinteraksi juga menggunakan bahasa Indonesia, responden juga merespon dengan menggunakan bahasa Indonesia. Jika lawan tutur menggunakan bahasa daerah. Sebanyak 15 responden mengaku tidak setuju pada pernyataan kedelapan. Dari hasil pengamatan dan hasil wawancara, responden mengaku tidak setuju jika bahasa Indonesia lebih menarik. Karena responden merasa lebih mudah menggunakan bahasa daerah, dan sudah menjadi kebiasaan berkomunikasi dengan menggunakan bahasa daerah. dari 40 responden tidak ditemukan memilih alternatif jawaban sangat tidak setuju.

\section{Pernyataan 7}

Saya menggunakan bahasa Indonesia sebagai bahasa utama dalam berinteraksi dan berkomunikasi

Tabel 7

\begin{tabular}{lcc}
\hline Alternatif Jawaban & Frekuensi & Persentase \\
\hline Sangat Setuju & 4 & 10 \\
Setuju & 11 & 27,5 \\
Ragu-ragu & 8 & 20 \\
Tidak Setuju & 17 & 42,5 \\
Sangat Tidak Setuju & 0 & 0 \\
\hline
\end{tabular}

Jumlah $\quad 40 \quad 100 \%$

Sebanyak 4 responden memilih alternatif jawaban sangat setuju pada pernyataan menggunakan bahasa Indonesia sebagai bahasa utama dalam berinteraksi dan berkomunikasi karena sudah terbiasa menggunakan bahasa Indonesia sebagai bahasa utama dalam berinteraksi dan berkomunikasi. Sebanyak 11 responden setuju memberikan alasan jika bahasa Indonesia lebih santai digunakan dan sudah menjadi kebiasaan menggunakan bahasa Indonesia dari pada bahasa daerah. Kemudian 8 responden memilih alternatif jawaban ragu-ragu, karena responden menggunakan bahasa Indonesia dalam komunikasi sehari-hari, tergantung situasi yang mereka hadapi. Jika lawan tuturnya menggunakan bahasa daerah, mereka juga akan membalas berkomunikasi dengan menggunakan bahasa daerah. Jika lawan tuturnya menggunakan bahasa Indonesia mereka juga akan menggunakan bahasa Indonesia. ketika berada disituasi yang dominan menggunakan bahasa Indonesia. Namun responden tetap cenderung menggunakan bahasa daerah ketika berkomunikasi. Selanjutnya 17 responden memilih tidak setuju. Responden mengaku bahasa Indonesia tidak digunakan sebagai bahasa utama dalam berinteraksi dan berkomunikasi karena mereka lebih dominan menggunakan bahasa daerah sebagai bahasa utama dalam berinteraksi dan berkomunikasi. Bahasa daerah sudah terbiasa digunakan dalam berinteraksi dan berkomunikasi jika berada dilingkungan tempat tinggalnya.

Kesimpulan dari ciri kebanggaan bahasa Indonesia pada pernyataan 4, 5, 6, dan 7 tidak memenuhi indikator sikap bahasa yang berkaitan dengan kebanggaan terhadap bahasa Indonesia. Kebanggaan bahasa Indonesia yang dimiliki responden terbilang negatif. Responden cenderung bangga terhadap bahasa daerah. Mereka hanya sekedar mengatakan bangga terhadap bahasa Indonesia. Namun tindakan responden dan 
sebagian masyarakat dusun Mangento yang diamati penulis ketika berinteraksi dan berkomunikasi cenderung menggunakan bahasa daerah.

c) Kesadaran akan adanya norma bahasa

Kesadaran akan adanya norma bahasa dapat diihat ketika seseorang menggunakan bahasanya dengan santun dan tidak seenaknya saja menggunakan bahasa. Melainkan dengan aturan-aturan. Seperti menggunakan bahasa yang sopan dan santun ketika berbicara pada lawan tutur.

\section{Pernyataan 8}

Saya menguasai bahasa Indonesia dengan segala aturan-aturannya

Tabel 8

\begin{tabular}{lcc}
\hline \multicolumn{1}{c}{ Alternatif Jawaban } & Frekuensi & Persentase \\
\hline Sangat Setuju & - & - \\
Setuju & 2 & 5 \\
Ragu-ragu & - & - \\
Tidak Setuju & 34 & 85 \\
Sangat Tidak Setuju & 4 & 10 \\
\hline \multicolumn{1}{c}{ Jumlah } & 40 & $100 \%$
\end{tabular}

Pada pernyataan saya menguasai bahasa Indonesia dengan segala aturanaturannya tidak ditemukan responden yang memilih sangat setuju. Kemudian hanya 2 responden mengaku setuju. Responden nomor urut 4 mengaku alasan menguasai bahasa Indonesia dengan segala aturan-aturannya karena jika disekolah, responden harus menggunakan bahasa Indonesia yang baik ketika pembelajaran dan diskusi berlangsung. tidak ditemukan jawaban ragu-ragu pada pernyataan kedelapan. angket yang berkaitan tentang kesadaran norma bahasa lebih dominan responden memilih alternatif jawaban tidak setuju dan sangat tidak setuju, dengan rincian 34 responden memilih tidak setuju dan 4 responden mengaku sangat tidak setuju pada pernyataan mengenai kesadaran norma bahasa. Responden yang tidak setuju dominan menggunakan bahasa daerah, orang tua juga sering menggunakan bahasa daerah dari pada bahasa Indonesia, itulah alasan responden tidak menguasai bahasa Indonesia dengan segala aturannya. Selanjutnya responden nomor urut 25 mengaku sangat tidak setuju menguasai bahasa Indonesia dengan segala aturan-aturannya karena responden hanya berpendidikan sampai sekolah dasar.

\section{Pernyataan 9}

Saya berusaha memperbaiki penggunaan bahasa Indonesia dengan terus mempelajari kaidah bahasa Indonesia

Tabel 9

\begin{tabular}{lcc}
\hline Alternatif Jawaban & Frekuensi & Persentase \\
\hline Sangat Setuju & 3 & 7,5 \\
Setuju & 14 & 35 \\
Ragu-ragu & - & - \\
Tidak Setuju & 23 & 57,5 \\
Sangat Tidak Setuju & - & - \\
\hline \multicolumn{1}{c}{ Jumlah } & 40 & $100 \%$ \\
\hline
\end{tabular}

sebesar 3 responden mengaku sangat setuju dan 14 responden setuju pada pernyataan tersebut. Responden mengaku sangat setuju karena responden merasa bahasa Indonesia yang di gunakan belum begitu baik menurutnya makanya responden harus berusaha mempelajari kaidah bahasa Indonesia. Selanjutnya responden memilih 
alternatif jawaban setuju karena alasan tidak selamanya responden berada dilingkungan tempat tinggalnya yang dominan menggunakan bahasa daerah. suatu saat responden akan berinteraksi dengan orang-orang yang dominan menggunakan bahasa Indonesia. maka dari itu responden mengaku harus berusaha memperbaiki penggunaan bahasa Indonesia dan terus mempelajari kaidah bahasa Indonesia. Sejumlah 23 responden memilih alternatif jawaban tidak setuju. Responden mengaku tidak perlu memperbaiki penggunaan bahasa Indonesia. karena lawan tutur paham dan mengerti ketika responden menggunakan bahasa Indonesia. responden juga beralasan karena bahasa yang digunakan dalam keseharian adalah bahasa daerah yang perlu memperbaiki penggunaan bahasa daerah tuturnya adalah anak-anak yang masih duduk di bangku sekolah. Agar mereka dapat berkomunikasi dengan teman-teman dan gurunya menggunakan bahasa Indonesia yang baik. Pada pernyataan angket yang berkaitan tentang kesadaran norma bahasa tidak ditemukan responden yang memilih alternatif jawaban ragu-ragu dan sangat tidak setuju.

\section{Pernyataan 10}

Saya berbicara dengan orang yang lebih tua dengan menggunakan bahasa Indonesia yang baik

Tabel 10

\begin{tabular}{lcc}
\hline Alternatif Jawaban & Frekuensi & Persentase \\
\hline Sangat Setuju & - & - \\
Setuju & 13 & 32,5 \\
Ragu-ragu & 13 & 32,5 \\
Tidak Setuju & 14 & 35 \\
Sangat Tidak Setuju & - & - \\
\hline \multicolumn{1}{c}{ Jumlah } & 40 & $100 \%$ \\
\hline
\end{tabular}

Seseorang menunjukkan sikap positif bahasa ketika ia menggunakan bahasa Indonesia dengan baik ke semua orang. Menggunakan bahasa Indonesia yang baik artinya sopan dan santun. Sejumlah 13 responden memilih jawaban setuju. Menurut dari pengakuan responden terkait kesadaran akan adanya norma bahasa, responden nomotr urut 2 menggunakan bahasa Indonesia yang baik jika lawan tutur yang ditemani berkomunikasi menggunakan bahasa Indonesia. Responden merasa lebih sopan ketika berbicara dengan bahasa Indonesia yang baik kepada orang yang lebih tua yang dominan menggunakan bahasa Indonesia ketika berkomunikasi. Sebanyak 13 responden menjawab ragu-ragu, dengan alasan ketika diwawancarai, mereka mengaku jika responden menggunakan dua bahasa dalam berkomunikasi. Responden mengaku menggunakan bahasa Indonesia dan bahasa daerah yang baik ketika berbicara dengan orang yang lebih tua Tergantung situasi yang mereka hadapi. Sementara itu 14 responden ada pada pilihan jawaban tidak setuju. Responden mengaku canggung dan tidak terbiasa menggunakan bahasa Indonesia ketika berbicara kepada orang yang lebih tua dari responden. Karena dari dulu mereka lebih dominan menggunakan bahasa daerah ketika berkomunikasi.

Dari sikap bahasa yang ketiga yaitu kesadaran akan adanya norma bahasa dapat disimpulkan bahwa sikap bahasa masyarakat yang berkaitan dengan indikator kesadaran akan adanya norma bahasa adalah negatif. Hal tersebut didukung dari banyaknya responden yang tidak menguasai bahasa Indonesia dengan segala aturanaturannya dan responden lebih banyak yang memilih alternatif jawaban tidak setuju pada pernyataan tentang kesadaran norma bahasa. 


\section{Simpulan}

Berdasarkan dari pembahasan yang telah diuraikan mengenai sikap bahasa masyarakat Dusun Mangento Desa Pattontongan terhadap penggunaan bahasa

Indonesia, terdapat simpulan sebagai berikut:

1) Sikap bahasa masyarakat Dusun Mangento Desa Pattontongan terhadap penggunaan bahasa Indonesia memperoleh hasil yang negatif. Dari 10 pernyataan yang disajikan dalam angket, dan hasil wawancara tidak terstruktur serta pengamatan yang dilakukan penulis, ditemukan lebih dominan menggunakan sikap negatif terhadap penggunaan bahasa Indonesia. Dengan persentase sangat setuju 8,5\% dan setuju $34,5 \%$. Kemudian jawaban ragu-ragu $18 \%$, tidak setuju $38 \%$ dan sangat tidak setuju $1 \%$. Hasil negatif tertinggi ada pada alternatif jawaban tidak setuju yakni sebesar $38 \%$.

2) Hasil wawancara dan pengamatan, hampir keseluruhan responden tidak setuju menguasai bahasa Indonesia dengan segala aturan-aturannya. Ketika berinteraksi dan berkomunikasi masyarakat cenderung menggunakan bahasa daerah. Responden hanya sekedar mengaku menyukai bahasa Indonesia tetapi dalam tindakan ketika berinteraksi dan berkomunikasi masyarakat Dusun Mangento Desa Pattontongan dominan menggunakan bahasa daerah.

\section{Saran}

Berdasarkan hasil penelitian yang telah dilakukan maka terdapat beberapa saran yang dapat diberikan adalah sebagai berikut:

1) Hendaknya penggunaan bahasa Indonesia pada masyarakat di Dusun Mangento Desa Pattontongan lebih ditingkatkan lagi baik dalam lingkungan yang formal maupun tidak formal. Karena masyarakat tidak hanya berinteraksi di lingkungan tempat tinggalnya melainkan juga berinteraksi dan berkomunikasi di luar dari lingkungan tempat tinggalnya.

2) Bahasa daerah juga perlu digunakan. Namun kita harus menempatkan kapan bahasa daerah itu digunakan. Seharusnya orang tua harus membiasakan anak-anak menggunakan bahasa Indonesia ketika berkomunikasi agar generasi penerusnya dapat menggunakan bahasa Indonesia sebagai alat penghubung antar daerah dan suku bangsa.

\section{Daftar Pustaka}

Chaer, Abdul.2013. Pembinaan Bahasa Indonesia

Chaer, Abdul dan Leonie Agustina.2014. Sosiolinguistik perkenalan awal. Jakarta: Rineka Cipta.

Fitriana. 2015. Mixed Methods Reseach. Diunduh di https://batukehidupan.blogspot.com/2015/11/mixed-methodsresearch.html?m=1 tanggal 13 Mei 2020.

Kalfika, K. D., Wardani, A., Gosong, M., Artawan, G., \& Ganesha, U. P. (2013). Sikap Bahasa Siswa Terhadap Bahasa Indonesia: Studi Kasus Di SMA Negeri 1 Singaraja. EJournal Program Pascasarjana Universitas Pendidikan Ganesha, 2(1).

Padmadewi, N. N. dkk.2014. Sosiolinguistik. Yogyakarta. Graha Ilmu

Raharjo, Sahid. 2013. Teori Sampel dan Sampling Penelitian. Diunduh di https://www.konsistensi.com//2013/04/teori-sampel-dan-samplingpenelitian.html?m=1 tanggal 17 Juli 2020.

Rokhman, Fathur.2013. Sosialinguistik Suatu Pendekatan Pembelajaran Bahasa dalam Masyarakat Multikultural. Yogyakarta: Graha Ilmu.

Halaman | 232 